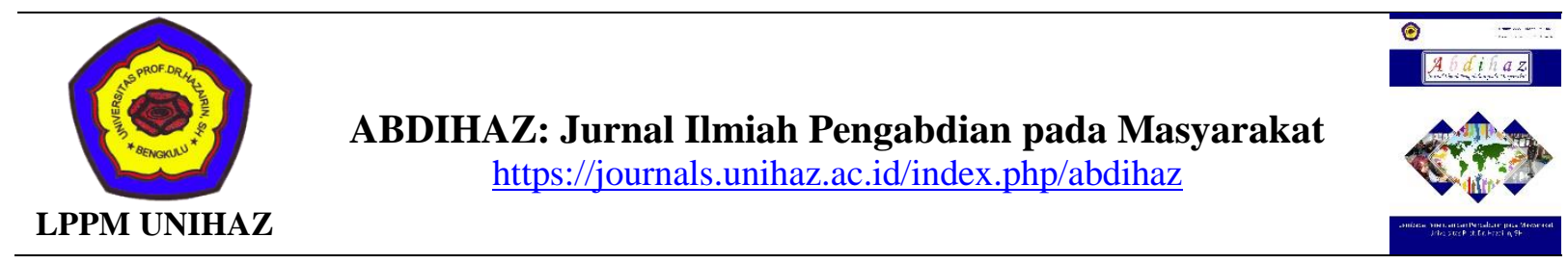

\title{
Diversifikasi Produk Stik Substitusi Kunir Putih di Karang Taruna Yodha Desa Argomulyo
}

\section{Product Diversification of White Saffron Substitute Stick in Karang Taruna Yodha, Argomulyo Village}

\author{
Bayu Kanetro, Dwiyati Pujimulyani*, Umul Aiman
}

Fakultas Agroindustri, Universitas Mercu Buana Yogyakarta, Jl. Wates KM 10 Yogyakarta, Indonesia

\begin{tabular}{l}
\hline Info Artikel \\
\hline Diterima 08 Desember 2021 \\
Ditelaah 20 Desember 2021 \\
Disetujui 25 Desember 2021 \\
Tersedia daring 30 Desember \\
2021 \\
*Penulis untuk \\
korespondensi \\
dwiyati @ mercubuana- \\
yogya.ac.id \\
\hline Kata Kunci: \\
Antioksidan, budidaya \\
empon-empon, fenol total, \\
stik \\
\hline
\end{tabular}

Keywords:

Antioxidants, cultivation of empon-empon, sticks, total phenol

\begin{abstract}
ABSTRAK
Jogja Youth Farming (JYF) adalah agrowisata yang pengembangannya dilakukan oleh karang taruna Yodha Desa Argomulyo, Sedayu, Kabupaten Bantul, Daerah Istimewa Yogyakarta. Upaya yang dilakukan untuk pengembangan Agrowisata JYF ialah melalui hilirisasi penelitian. Hasil survei tim pengabdi menemukan bahwa karang taruna Yodha memiliki potensi untuk mengembangkan wirausaha pangan fungsional yang berbasis empon-empon lokal dari wilayah desa Argomulyo. Selain itu, di sekitar Agrowisata masih banyak ditemukan lahan subur yang masih kosong (lahan tidur) yang belum digunakan secara intensif. Tujuan kegiatan pengabdian pada masyarakat ini adalah untuk mengembangkan potensi wirausaha karang taruna Yodha di Desa Argomulyo. Pengembangan potensi dengan menyiapkan bahan dasar emponempon melalui budidaya yang baik dan pengolahan stik yang unggul (mempunyai aktivitas antioksidan) dan disukai konsumen. Solusi yang ditawarkan adalah melakukan pelatihan dan praktek budidaya empon-empon dan cara pengolahannya menjadi pangan fungsional, berupa produk (stik). Karang taruna JYF sudah menghasilkan stik dengan penambahan emponempon dan stik yang disukai konsumen dengan penambahan kunir putih $10 \%$.

\section{ABSTRACT}

Jogja Youth Farming (JYF) is an agro-tourism development carried out by Yodha youth organizations in Argomulyo Village, Sedayu, Bantul Regency, Special Region of Yogyakarta. Efforts are being made to develop JYF Agrotourism through downstream research. The survey results of the service team found that the Yodha youth organization had a potential to develop functional food entrepreneurs based on local rhizome plants (called as emponempon) from the Argomulyo village area. In addition, around Agrotourism there are still many vacant fertile lands (idle land) that have not been used intensively. The purpose of this community service activity was to develop the entrepreneurial potential of the Yodha youth organization in Argomulyo Village. Development of potential by preparing the basic ingredients of emponempon through good cultivation and processing of sticks, which are superior (have antioxidant activity) and are favored by consumers. The solution offered was to conduct training and practice on empon-empon cultivation and how to process it into functional food, sticks product. The JYF youth organization has produced sticks with the addition of empon-empon and sticks that consumers like with the addition of $10 \%$ white saffron.

ISSN 2685-0354 (Media Online). Diterbitkan oleh Universitas Prof. Dr. Hazairin, SH. Ini merupakan jurnal bebas akses di bawah lisensi Creative Commons Atribution 4.0 International. 


\section{PENDAHULUAN}

Desa Argomulyo berada di wilayah Kapanewon Sedayu, Kabupaten Bantul, Yogyakarta. Masyarakat desa Argomulyo sebagian besar mempunyai mata pencaharian di bidang pertanian baik sebagai petani pemilik yang sekaligus penggarap dan sebagian besar sebagai petani penggarap saja dengan tingkat ekonomi yang masih rendah. Kondisi ekonomi keluarga berkaitan erat dengan manajemen ekonomi keluarga, pendapatan keluarga, jenis peluang dalam meningkatkan kesejahteraan keluarga serta jenis mata pencaharian yang dimiliki. Jogja Youth Farming (JYF) adalah agrowisata yang pengembangannya dilakukan oleh karang taruna Yodha Desa Argomulyo.

Jarak tempuh antara JYF dengan Universitas Mercu Buana Yogyakarta hanya $2 \mathrm{~km}$, sehingga mudah melakukan pendampingan. Secara umum, kondisi agrowisata di JYF masih memerlukan penataan dan pengembangan. Hal ini karena terbatasnya pengetahuan tentang pengolahan pangan fungional dan cara budidaya empon-empon pada karang taruna Yodha. Karang taruna Yodha memiliki potensi yang sangat baik untuk mengembangkan kegiatan yang berkaitan dengan budidaya dan pengolahan. Kegiatan yang dilaksanakan di kelompok ini antara lain adalah upaya pengembangan agrowisata dan pengelolaan hilirisasi penelitian. Potensi Agrowisata JYF sangat baik, namun belum dikelola secara optimal. Saat ini, salah satu produk yang telah dikembangkan adalah pengolahan sambal. Diperlukan inovasi baru dalam menjaga eksistensi agrowisata JYF dengan diversifikasi pengolahan empon-empon. Pemanfaatan lahan sekitar JYF untuk budidaya empon-empon diharapakan mampu meningkatkan minat masyarakat maupun wisatawan dalam budidaya dan berwirausaha pangan fungsional.

Penerapan cara penanaman empon-empon dan pengolahannya akan berhasil jika didukung oleh ketekunan dan semangat masyarakat anggota karang taruna untuk maju dan mandiri. Keberadaan anggota karang taruna yang kompak, disiplin dengan didukung oleh unsur pemerintah mulai tingkat RT, RW, kepala dukuh, perangkat desa hingga kepala desa dan peran aktif pendampingan dari perguruan tinggi. Oleh karena itu, program ini diyakini berhasil diterapkan secara baik.

Keberadaan dan semangat kerja mitra akan sangat mendukung penerapan teknologi pengolahan dan budidaya empon-empon di karang taruna Yodha khususnya, dan masyarakat desa Argomulyo pada umumnya. Disamping itu dari hasil wawancara dengan mitra selama dilakukan survey ternyata mitra memandang teknologi ini akan benar-benar bermanfaat terutama untuk meningkatkan pendapatan masyarakat melalui usaha penanaman empon-empon secara intensif dan pengolahan pangan fungsional stik. Hal lain yang mendukung pemanfaatan teknologi ini adalah sudah terbentuk usaha karang taruna Yodha yang terorganisasi dengan baik, sehingga mendukung semangat berwirausaha anggotanya.

Karang taruna Yodha sudah memulai berwirausaha sambal untuk mendukung keberlangsungan agrowisata tetapi belum optimal. Oleh karena itu, perlu ditambah produk diversifikasi berupa olahan pangan fungsional berbahan dasar empon-empon yang kaya akan antioksidan dan disukai konsumen. Kendala karang taruna Yodha sebagai wirausaha baru adalah minimnya pengetahuan pengemasan dan pemasaran, sehingga pemasaran produk belum optimal.

Produk olahan pangan fungsional di antaranya seperti stik dapat diharapkan mendukung pengembangan agrowisata JYF. Berdasarkan penelitian yang telah dilakukan diketahui bahwa rimpang kunir putih yang diolah menjadi cookies manis menunjukkan aktivitas antioksidan cukup tinggi, walaupun melalui proses pengolahan dengan pemanggangan (Pujimulyani \& Wazyka, 2008). Berdasarkan potensi agrowisata JYF dan hasil penelitian yang telah diuraikan tersebut 
maka budidaya dan teknologi pengolahan empon-empon tepat untuk dikembangkan karang taruna Yodha wilayah desa Argomulyo, Sedayu, Kabupaten Bantul, Daerah Istimewa Yogyakarta.

Tujuan kegiatan pengabdian kepada masyarakat (PKM) ini adalah untuk mengembangkan potensi wirausaha karang taruna Yodha di Desa Argomulyo dengan meningkatkan nilai ekonomi empon-empon melalui budidaya yang baik sehingga mendapatkan hasil yang maksimal. Tujuan khusus PKM ini melakukan penyuluhan. Pelatihan budidaya empon-empon dan pengolahan pangan fungsional berupa stik, yang unggul (mempunyai aktivitas antioksidan) dan memiliki akseptabilitas tinggi.

\section{METODE}

Kegiatan PKM ini dilaksanakan selama bulan Maret 2021 di Karang Taruna Yodha Desa Argomulyo Kapanewon Sedayu, Kabupaten Bantul, Yogyakarta. Kegiatan PKM dilaksanakan dengan dalam bentuk penyuluhan dan pelatihan/praktik untuk memproduksi pangan fungsional unggulan berupa stik dan budidaya empon-empon (contoh: kunir putih, kencur, kunyit dan temulawak) dalam rangka memenuhi kebutuhan bahan dasar dan meningkatkan penghasilan.

Program Kemitraan Masyarakat dapat berhasil dengan baik, karena tim pengabdi bekerja sama dengan mitra. Tujuan kerja sama adalah agar dapat mendorong anggota karang taruna untuk memproduksi pangan fungsional unggul yaitu stik yang akan diberikan oleh tim pengabdi dan dapat membuat kebijakan untuk mendorong masyarakat membudidayakan secara intensif dan mengolah empon-empon dengan metode yang diberikan. Partisipasi mitra dalam rencana pelaksanaan program ditunjukkan dengan adanya dukungan dan kesanggupan kerja sama sebagai mitra dengan tim pengabdi dari Universitas Mercu Buana Yogyakarta dalam penerapan PKM. Partisipasi mitra juga ditunjukkan dengan kerja sama membuat perencanaan program. Program disiapkan dan dilaksanakan secara bersama-sama yaitu perencanaan kegiatan pendidikan/ penyuluhan dan pelatihan, pendampingan, penanaman dan pengolahan. Evaluasi pelaksanaan program kemitraan masyarakat dan keberlanjutan program meliputi evaluasi luaran yang ditargetkan dan melakukan pendampingan serta selalu berkomunikasi untuk membantu pengembangan produk pangan fungsional unggulan yaitu stik.

Langkah-langkah awal kegiatan PKM adalah koordinasi dan kerja sama dengan mitra untuk memotivasi masyarakat terutama karang taruna Yodha agar bersedia dengan senang mengikuti pelatihan. Pada tahap pelaksanaan, pendidikan dan pelatihan (Diklat) dilaksanakan untuk perubahan mindset anggota karang taruna Yodha dari memasarkan empon-empon dalam bentuk segar ke profit oriented menggunakan penerapan teknologi pengolahan. Selain itu, diklat budidaya empon-empon agar lahan kosong di desa Argomulyo ditanami secara intensif dan agar bahan dasar untuk pengolahan produksi pangan fungsional terjamin ketersediaannya dengan kualitas yang baik. Anggota karang taruna Yodha juga dilatih dalam pengolahan empon-empon menjadi pangan fungsional yang unggul dan berkualitas tinggi. Contohnya, bimbingan dan pendampingan produksi pangan fungsional dari kunir putih yang berkualitas dilakukan. Selain pendampingan, tim pengabdi juga memberikan bantuan peralatan pengolahan dan budidaya serta pendampingan penggunaan alat-alat yang telah diberikan pada karang taruna Yodha. Kemudian, pendidikan/penyuluhan dan pelatihan tentang kewirausahaan dan teknik pemasaran pangan fungsional diberikan untuk mendukung produksi pangan fungsional tersebut hingga terjual.

Dengan pengetahuan/pelatihan yang telah diterapkan, diharapkan produk pangan fungsional yang dihasilkan oleh karang taruna Yodha di desa Argomulyo mempunyai kualitas yang baik. 
Produk pangan fungsional yang dihasilkan disukai dan mempunyai daya simpan lebih lama, sehingga pemasaran lebih luas. Jumlah produk olahan dapat ditingkatkan, sehingga dapat mendukung peningkatkan kesejahteraan masyarakat.

Tahap pertama adalah pembuatan stick mocaf-terigu yaitu dengan menentukan perbandingan mocaf : terigu. Berdasarkan orientasi yang telah dilakukan diperoleh rasio mocaf : terigu terbaik ialah 50 : 50. Ratio mocaf : terigu terbaik tersebut kemudian ditambahkan dengan bubuk kunir putih dengan variasi $10 \mathrm{~g}$ serta baking powder sebanyak 0,30 g. Stick mocaf-terigu yang dihasilkan dilakukan uji tingkat kesukaan (Lestari, 2021). Stick mocaf-terigu yang paling disukai kemudian dilakukan analisa fisik dan kimia (Gambar 1).

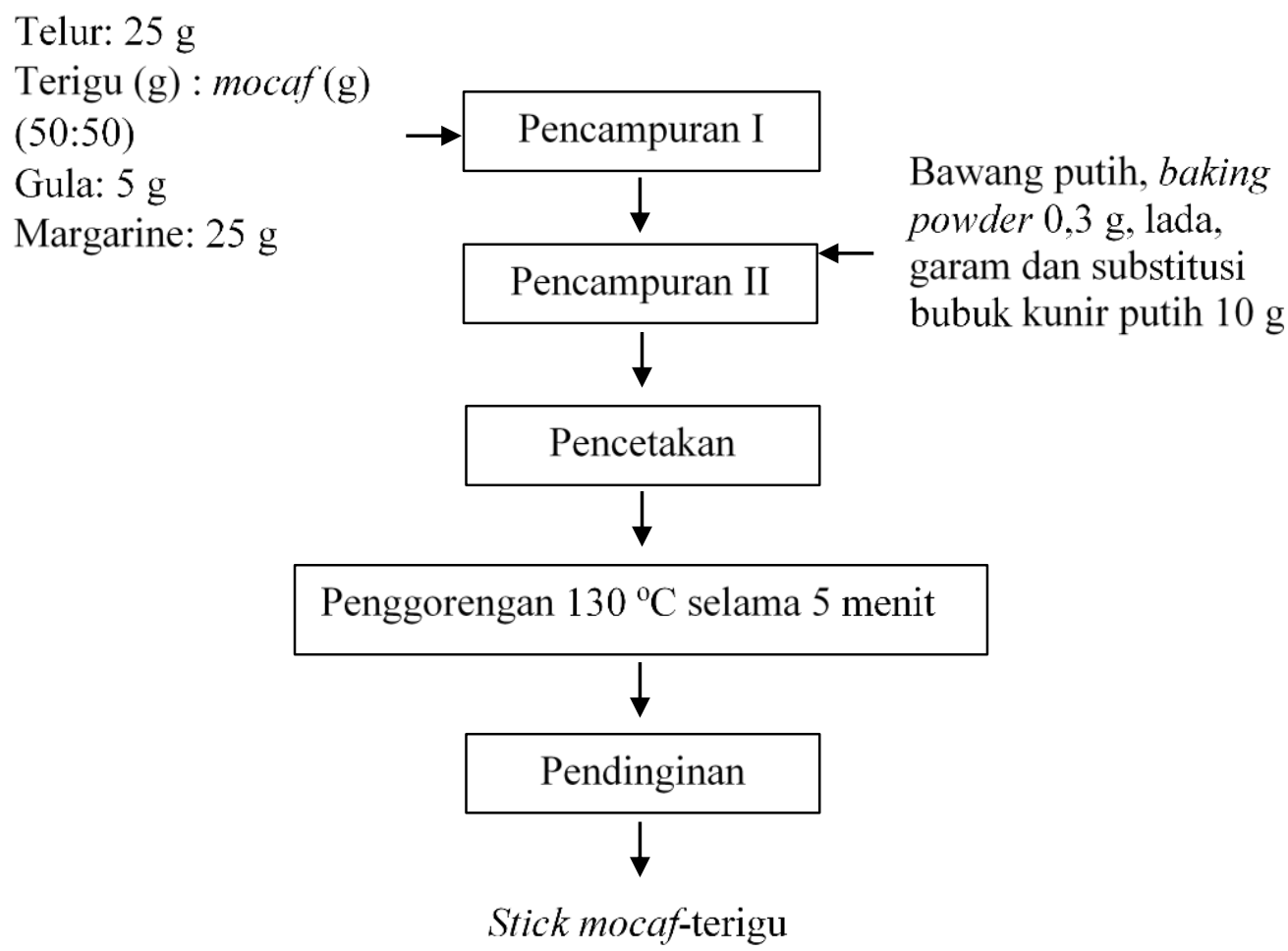

Gambar 1 Diagram alir pembuatan stick mocaf-terigu

\section{HASIL DAN PEMBAHASAN}

Koordinasi dengan karang taruna Yodha merupakan langkah awal untuk mengadakan pertemuan dan melakukan Penerapan Teknologi Pengolahan empon-empon dan budidayanya. Pelaksanaan diklat PKM Desa Argomulyo untuk Penerapan Teknologi Pengolahan Empon-empon dan Budidayanya telah dilaksanakan pada Sabtu tanggal 20 Maret 2021 pada pukul 08.00 WIB sampai selesai bertempat di Joglo JYF Dusun Watu, Argomulyo, Kapanewon Sedayu peserta berjumlah 22 orang dan praktik pengolahan dilakukan pada Minggu, 21 Maret 2021 pada pukul 08.00 WIB sampai selesai bertempat di Watu, Argomulyo, Kecamatan Sedayu. Peserta berjumlah 20 orang.

Antusias anggota karang taruna Yodha terlihat jelas dengan banyaknya anggota yang datang mengikuti pelatihan. Selain itu semangat karang taruna juga terbukti dengan banyak pertanyaan yang diajukan pada narasumber (Dr. Bayu Kanetro, Prof. Dwiyati dan Dra. Umul Aiman). Hasil yang dicapai lainnya adalah praktik pengolahan oleh karang taruna juga berlangsung dengan lancer (Gambar 2, Gambar 3, Gambar 4, Gambar 5). 


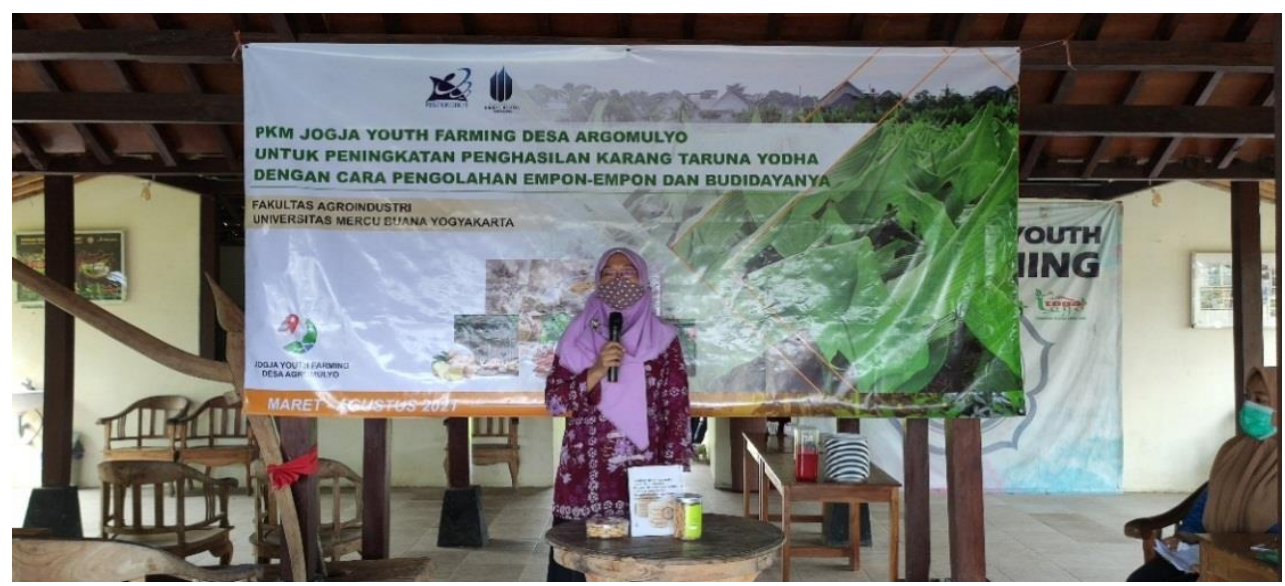

Gambar 2 Penyuluhan tentang pengolahan pangan fungsional stick

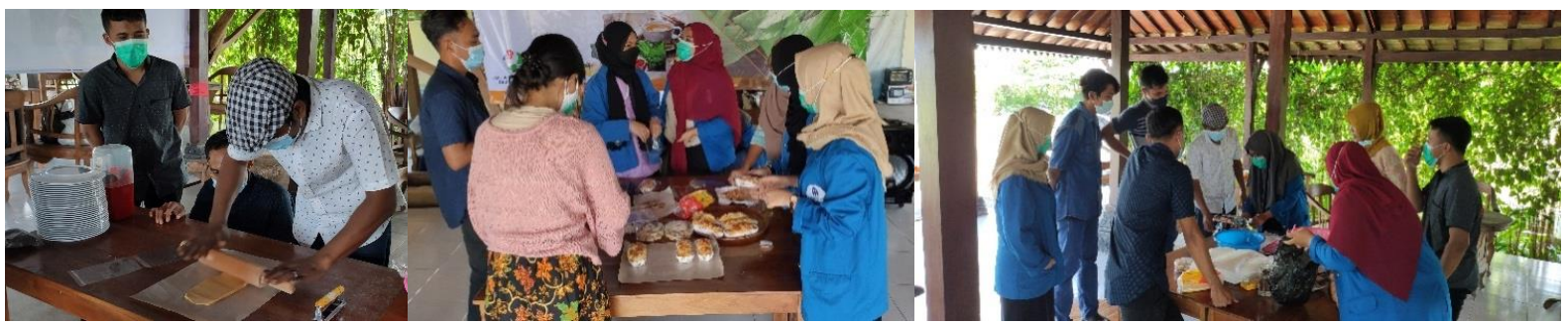

Gambar 3 Praktek penyuluhan penerapan teknologi pengolahan empon-empon

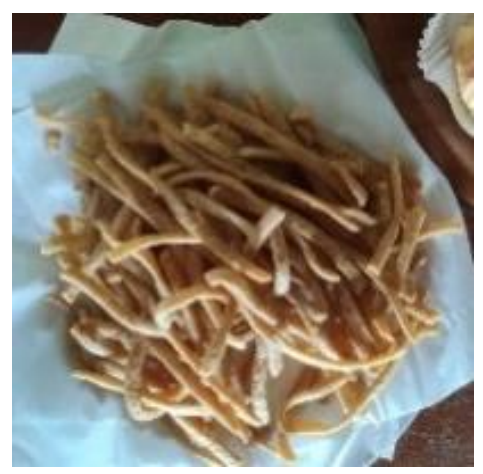

Gambar 4 Produk hasil penyuluhan penerapan teknologi pengolahan empon-empon

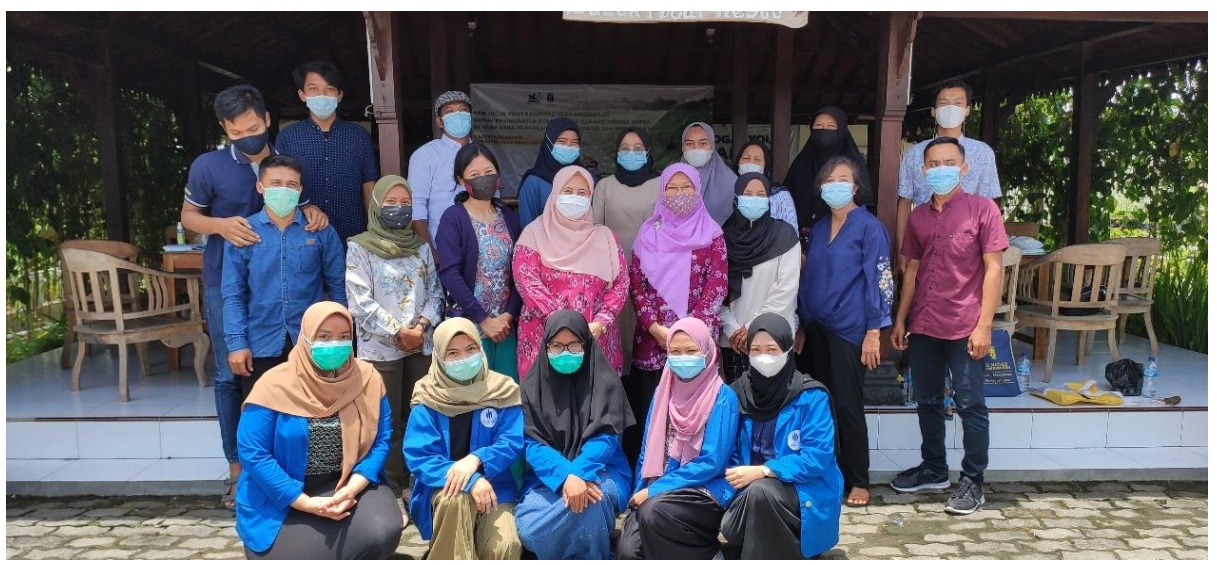

Gambar 5 Peserta pelatihan dan tim pengabdi 
Tabel 1 Tingkat kesukaan stick mocaf-terigu

\begin{tabular}{lllllll}
\hline $\begin{array}{l}\text { Formulasi } \\
\begin{array}{l}\text { Bubuk kunir putih } \\
(\mathrm{g})\end{array}\end{array}$ & $\begin{array}{l}\text { Baking powder } \\
(\mathrm{g})\end{array}$ & Warna & Aroma & Tekstur & Rasa & Keseluruhan \\
\hline 0 & 0 & & & & & \\
5 & 0,15 & $3.50^{\mathrm{d}}$ & 2,70 & 3,10 & $2,85^{\mathrm{abc}}$ & $3,10^{\mathrm{bc}}$ \\
5 & $3,55^{\mathrm{d}}$ & 3,05 & 2,85 & $2,90^{\mathrm{abc}}$ & $3,05^{\mathrm{bc}}$ \\
5 & 0,30 & $3,25^{\mathrm{d}}$ & 2,85 & 3,20 & $3,15^{\mathrm{d}}$ & $3,15^{\mathrm{bc}}$ \\
10 & 0,45 & $3,40^{\mathrm{cd}}$ & 3,25 & 3,20 & $2,70^{\mathrm{abc}}$ & $3,00^{\mathrm{b}}$ \\
10 & 0,15 & $2,75^{\mathrm{abc}}$ & 3,00 & 3,10 & $3,00^{\mathrm{bc}}$ & $3,05^{\mathrm{bc}}$ \\
10 & 0,30 & $3,50^{\mathrm{d}}$ & 3,55 & 3,25 & $3,25^{\mathrm{d}}$ & $3,65^{\mathrm{c}}$ \\
15 & 0,45 & $2,50^{\mathrm{ab}}$ & 3,10 & 2,70 & $2,55^{\mathrm{abc}}$ & $2,70^{\mathrm{ab}}$ \\
15 & 0,15 & $2,85^{\mathrm{abcd}}$ & 3,15 & 2,85 & $2,35^{\mathrm{ab}}$ & $2,75^{\mathrm{ab}}$ \\
15 & 0,30 & $3,00^{\mathrm{bcd}}$ & 3,10 & 3,05 & $2,65^{\mathrm{abc}}$ & $2,95^{\mathrm{ab}}$ \\
\hline
\end{tabular}

Sumber: Lestari (2021)

Stick mocaf-terigu dengan penambahan bubuk kunir putih dan baking powder mempengaruhi penerimaan panelis (Tabel 1). Stick mocaf-terigu terpilih berdasarkan jumlah bubuk kunir putih dan baking powder yang ditambahkan. Jumlah kunir putih yang digunakan diharapkan dapat meningkatkan aktivitas antioksidan dari stick mocaf-terigu. Selain itu pemilihan juga ditujukan pada produk dengan penambahan baking powder yang paling sedikit. Sehubungan dengan hal tersebut maka stick mocaf-terigu terpilih dalam adonan (100 g) yaitu penambahan bubuk kunir putih $10 \mathrm{~g}$ dan baking powder 0,30 g (Lestari, 2021).

\section{Aktivitas antioksidan}

Aktivitas antioksidan pada stick mocaf-terigu terpilih adalah 29,80\% (Lestari, 2021). Aktivitas antioksidan tinggi diduga disebabkan penggunaan bahan bubuk kunir putih yang memiliki aktivitas antioksidan 70,83\% RSA (Pujimulyani, 2013). Penelitian Curcuma mangga Val. yang telah dilakukan oleh Lestariana et al. (2000) menunjukkan bahwa cairan hasil perasan rimpang mempunyai aktivitas sitotoksik terhadap limfoblastoid yang diturunkan dari sel limfosit penderita kanker tetapi tidak sitotoksik terhadap sel limfosit orang sehat. Nurkhasanah (2002) menyatakan bahwa minyak atsiri Curcuma mangga Val. mempunyai aktivitas sitotoksik terhadap sel kanker HeLa S3 dan sel Raji. Sifat sitotoksik ekstrak kunir putih tersebut diduga berkaitan dengan komponen antioksidan.

Pengolahan kunir putih yang telah dilakukan menunjukkan ekstrak kunir putih mampu menghambat oksidasi, karena ekstrak kunir putih mengandung kurkuminoid (Pujimulyani \& Sutardi, 2003). Tahap pemanasan pada proses pengolahan sirup kunir putih menunjukkan hasil olahan tetap mempunyai aktivitas antioksidan Radical Scavenging Activity (RSA) 25,51\% (Pujimulyani \& Wazyka, 2005). Berdasarkan hal tersebut, diduga komponen antioksidan dalam kunir putih tahan suhu tinggi atau terjadi perubahan senyawa tidak aktif/kurang aktif menjadi aktif. Beberapa hasil penelitian menunjukkan bahwa blanching bahan hasil pertanian dapat meningkatkan aktivitas antioksidan. Puuponen-Pimia et al. (2003) melaporkan bahwa aktivitas antioksidan kobis meningkat 9\% dibanding tanpa blanching. Blanching pada jagung dapat meningkatkan kadar total fenol (Randhir et al., 2008). 
Aktivitas antioksidan pada kacang-kacangan, jagung, dan tomat yang diukur dengan metode DPPH meningkat setelah dilakukan blanching (Kwan et al., 2007). Kobis brussel (Brassica oleracea L.) dengan perlakuan perebusan $100^{\circ} \mathrm{C}$ selama 2 menit dan 3 menit mempunyai aktivitas antioksidan lebih tinggi dibanding kobis brussel segar (Viña et al., 2007). Peningkatan aktivitas antioksidan tersebut diduga karena perlakuan blanching dapat menyebabkan komponen antioksidan mudah lepas dari matrik sel, sehingga meningkatkan hasil ekstraksi. Hasil olahan kunir putih menunjukkan aktivitas antioksidan tinggi, misalnya Radical Scavenging Activity (RSA) manisan basah 42,94\% (Pujimulyani \& Wazyka, 2009a), manisan kering 40,68\% (Pujimulyani \& Wazyka, 2009b), sirup 25,51\% dan bubuk instan 27,09\% (Pujimulyani \& Wazyka, 2005). Hasil olahan tersebut diperoleh melalui tahap pemanasan, sehingga diduga komponen antioksidan dalam kunir putih tahan suhu tinggi atau diduga terjadi perubahan senyawa kurang aktif menjadi aktif.

\section{Kadar Fenol Total}

Kadar fenol total pada stick mocaf-terigu terpilih adalah 27,37 GAE/g bk. Hasil fenol total pada stick mocaf-terigu cukup tinggi. Kadar fenolik total pada stick mocaf-terigu ini hampir sama dengan fenolik total pada penelitian Paulina (2018) pada ekstrak bubuk kunir putih dengan penambahan filler (28,32-33,43 mg GAE/g). Semakin tinggi penambahan bubuk kunir putih yang digunakan, maka fenolik total juga akan semakin tinggi sehingga aktivitas antioksidannya juga akan semakin tinggi. Adapun kandungan fenol pada tanaman dipengaruhi oleh beberapa faktor, yaitu genetik, lingkungan dan teknologi yang diterapkan setelah proses pemanenan (Barberan \& Espin, 2001 dalam Fithriani et al., 2015).

Menurut Li et al (2007) peningkatan waktu pemanasan dapat menyebabkan penurunan kadar fenol total dalam bahan. Hal ini diduga senyawa fenol larut pada saat pemanasan. Selama pemanasan berhubungan langsung dengan panas yang dihasilkan pada saat pengovenan, sehingga dinding sel dan membran plasma cepat mengalami kerusakan. Aktivitas antioksidan berbanding lurus dengan total fenol, semakin tinggi kandungan fenol dalam suatu bahan semakin tinggi pula aktivitasnya sebagai antioksidan (Huang et al., 2005).

\section{KESIMPULAN}

Pendidikan dan pelatihan yang diterapkan pada program PKM di Desa Argomulyo menghasilkan produk pangan fungsional yaitu stik. Produk stik dibuat dengan perbandingan tepung terigu:mokaf yaitu 50:50 dengan penambahan kunir putih sebanyak $10 \mathrm{~g}$ dan baking powder $0,3 \mathrm{~g}$ dalam adonan sebanyak $100 \mathrm{~g}$.

\section{UCAPAN TERIMA KASIH}

Ucapan terima kasih disampaikan kepada Kementerian Riset, Teknologi dan Pendidikan Tinggi yang telah memberikan dana pengabdian kepada masyarakat tahun anggaran 2021.

\section{DAFTAR PUSTAKA}

Fithriani, D., Amini, S., Melanie, S., \& Susilowati, R. (2015). Uji fitokimia, kandungan total fenol dan aktivitas antioksidan mikroalga Spirulina Sp., Chlorella Sp., dan Nannochloropsis Sp. Jurnal Pascapanen dan Bioteknologi Kelautan dan Perikanan, 10(2), 101-109.

Huang, D., Ou, B., \& Prior, R. L. (2005). The chemistry behind antioxidant capacity assays. Journal of Agricultural and Food Chemistry, 53(6), 1841-1856 
Kwan, Y. I., Apostolidis, E., \& Shetty, K. (2007). Traditional diet of Americans for management of diabetes and hypertension. Journal of Medicinal Food, 10, 266-275.

Lestari, A. E. (2021). Pengaruh penambahan bubuk kunir putih (Curcuma mangga Val.) dan baking powder terhadap tingkat kesukaan, sifat fisik dan kimia stick mocaf-terigu [Skripsi]. Fakultas Agroindustri, Universitas Mercu Buana Yogyakarta.

Lestariana, W., Triandiasih, H., Sismindari, \& Mubarika, S. (2000). Identifikasi protein aktif dalam Curcuma mangga Val. dan uji aktivitasnya pada DNA Supercoil. Bulletin ISF, 3, 2530 .

Li, W., Pickard, M. D., \& Beta, T. (2007). Effect of thermal processing on antioxidant properties of purple wheat bran. Food Chemistry, 104(3), 1080-1086.

Nurkhasanah. (2002). Analisa GC-MS minyak atsiri Curcuma mangga val. dan uji sitotoksisnya terhadap sel kanker Raji dan Hela-S3. Fakultas Farmasi, Universitas Gadjah Mada Yogyakarta.

Paulina, R. P., \& Pujimulyani, D. (2018). Evaluasi sifat antioksidatif ekstrak bubuk kunir putih (Curcuma Mangga Val.) dengan variasi penambahan filler. Seminar Nasional Inovasi Produk Pangan Lokal Untuk Mendukung Ketahanan Pangan. Universitas Mercu Buana Yogyakarta (pp. 159-166).

Pujimulyani, D., Raharjo, S., Marsono, Y., \& Santoso, U. (2013). The phenolic substances and antioxidant activity of white saffron (Curcuma mangga Val.) as affected by blanching methods. World Acad. Sci. Eng. Technol, 7(10), 947-950.

Pujimulyani, D., \& Sutardi. (2003). Curcuminoid content and antioxidative properties on white saffron extract (Curcuma mangga Val.). Proceeding International Conference Redesigning Sustainable Development on Food and Agricultural System for Developing Countries, $517-$ 529.

Pujimulyani, D., \& Wazyka, A. (2005). Potensi kunir putih (Curcuma mangga Val.) sebagai sumber antioksidan untuk pengembangan produk makanan fungsional. Laporan Hasil Penelitian HIBAH PEKERTI Tahun II.

Pujimulyani, D., \& Wazyka, A. (2008). Potensi manisan kering, manisan basah dan biskuit dari kunir putih (Curcuma mangga Val.) sebagai pangan fungsional. Laporan Hasil Penelitian HIBAH BERSAING Tahun II.

Pujimulyani, D., \& Wazyka, A. (2009a). Sifat antioksidasi, sifat kimia dan sifat fisik manisan basah dari kunir putih (Curcuma mangga val.). Agritech, 29(3), 167-173.

Pujimulyani, D., \& Wazyka, A. (2009b). An antioxidant activity and curcumin content of dry sweets from white saffron (Curcuma mangga Val). In International Chemistry Seminar Proceeding (pp. 82-86).

Puuponen-Pimia, R., Hakkinen, S. T., Aarni, M., Suorlti, T., Lampi, A. M., \& Eurola, M. (2003). Blanching and long term freezing affect various bioactive compounds of vegetables in different ways. Journal of the Science of Food and Agriculture, 62, 259-265.

Randhir, R., Kwon, Y. I., \& Shetty, K. (2008). Effect of thermal processing on phenolics, antioxidant activity and health-relevant functionality of select grain sprouts and seedlings. Innovative Food Science \& Emerging Technologies, 9(3), 355-364.

Vina, S. Z., Olivera, D. F., Marani, C. M., Ferreyra, R. M., Mugridge, A., Chaves, A. R., \& Mascheroni, R. H. (2007). Quality of brussels sprouts (Brassica oleracea L. gemmifera DC) as affected by blanching method. Journal of Food Engineering, 80(1), 218-225. 